Correspondence Margarita Grabovich margarita_grabov@mail.ru

\section{Thiothrix caldifontis sp. nov. and Thiothrix lacustris sp. nov., gammaproteobacteria isolated from sulfide springs}

\author{
Elena Chernousova, ${ }^{1,2}$ Elena Gridneva, ${ }^{1}$ Margarita Grabovich, ${ }^{1}$ \\ Galina Dubinina, ${ }^{3}$ Vladimir Akimov, ${ }^{2}$ Simona Rossetti ${ }^{4}$ and Jan Kuever ${ }^{5}$ \\ ${ }^{1}$ Department of Biology, University of Voronezh, Universitetskaya pl. 1, 394006 Voronezh, Russia \\ ${ }^{2}$ G. K. Skryabin Institute of Biochemistry and Physiology of Microorganisms, Russian Academy of \\ Sciences, Prospect Nauki 5, 142290 Pushchino, Russia \\ ${ }^{3} \mathrm{~S}$. N. Winogradsky Institute of Microbiology, Russian Academy of Sciences, Prospect 60-letiya \\ Oktyabrya 7/2, 117312 Moscow, Russia \\ ${ }^{4}$ Water Research Institute, CNR, Via Reno 1, 00198 Rome, Italy \\ ${ }^{5}$ Department of Microbiology, Bremen Institute for Materials Testing, Paul-Feller-Str. 1, D-28199 \\ Bremen, Germany
}

\begin{abstract}
Five strains of filamentous, sulfur-oxidizing bacteria were isolated from sulfur mats of different sulfide springs from various regions of the Northern Caucasus, Russia. A phylogenetic analysis based on 16S rRNA gene sequence comparison showed that all of the isolates are affiliated with the filamentous, colourless, sulfur-oxidizing bacteria of the genus Thiothrix within the Gammaproteobacteria and are closely related to Thiothrix fructosivorans. All strains are capable of growing heterotrophically, lithoautotrophically with thiosulfate or sulfide as the sole energy source and mixotrophically. Strains $\mathrm{G} 1^{\top}, \mathrm{G} 2, \mathrm{P}$ and $\mathrm{K} 2$ are able to fix molecular nitrogen, but strain $\mathrm{BL}^{\top}$ is not. Randomly amplified polymorphic DNA (RAPD)-PCR analysis was used to assess the level of genetic relationships among the Thiothrix isolates. The Nei and Li similarity index revealed high genetic similarity among strains $G 1^{\top}, G 2, P$ and $K 2$ (above $75 \%$ ), indicating that they are closely related. In combination with physiological and morphological data, strains $\mathrm{G}^{\top}{ }^{\top}, \mathrm{G} 2, \mathrm{P}$ and $\mathrm{K} 2$ can be considered as members of the same species. The lowest genetic similarity (approx. $20 \%$ ) was reached between strain $\mathrm{BL}^{\top}$ and the other isolated Thiothrix strains. Strains $\mathrm{BL}^{\top}$ and $\mathrm{G}_{1}^{\top}$ shared $35 \%$ DNA-DNA relatedness and showed 51 and $53 \%$ relatedness, respectively, to Thiothrix fructosivorans ATCC 49749. On the basis of this polyphasic analysis, strains $\mathrm{G} 1^{\top}, \mathrm{G} 2$, $\mathrm{P}$ and $\mathrm{K} 2$ represent a novel species within the genus Thiothrix, for which the name Thiothrix caldifontis sp. nov. is proposed, with strain $\mathrm{G} 1^{\top}\left(=\mathrm{DSM} 21228^{\top}=\mathrm{VKM} \mathrm{B}-2520^{\top}\right)$ as the type strain. In addition, strain $\mathrm{BL}^{\top}$ represents a second novel species, Thiothrix lacustris sp. nov., with strain $\mathrm{BL}^{\top}\left(=\mathrm{DSM} 21227^{\top}=\right.$ VKM B-2521 $\left.1^{\top}\right)$ as the type strain.
\end{abstract}

The genus Thiothrix (family 'Thiothrichaceae', class Gammaproteobacteria) comprises seven species. On the basis of phylogenetic data, Thiothrix species are divided

Abbreviation: RAPD, randomly amplified polymorphic DNA.

The GenBank/EMBL/DDBJ accession numbers for the $16 \mathrm{~S}$ rRNA, gyrB and $h s p 60$ gene sequences of strains $\mathrm{G}^{\top}$ and $\mathrm{BL}^{\top}$ are respectively EU642573 and EU642572 (16S rRNA gene), FJ032200 and FJ032199 (gyrB) and FJ161077 and FJ161076 (hsp60).

RAPD patterns of newly isolated Thiothrix strains, 165 rRNA gene, hsp60 and gyrB sequence similarity matrices and DNA-DNA hybridization results are available as supplementary material with the online version of this paper. into two main groups. The Thiothrix nivea group, including $T$. nivea, $T$. unzii and $T$. fructosivorans, shows 88.3-92.0\% 16S rRNA gene sequence similarity to the Eikelboom type $021 \mathrm{~N}$ group, which includes Thiothrix disciformis, T. flexilis and T. eikelboomii. Thiothrix defluvii is closely related phylogenetically to $T$. flexilis strains of the Eikelboom type $021 \mathrm{~N}$ group, with 96.8-97.1\% 16S rRNA gene sequence similarity. However, this species is not a member of Eikelboom type 021N (Aruga et al., 2002). The names 'Thiothrix ramosa' and 'Thiothrix arctophila' have not been validly published and strain CT3 has not been assigned to a named species; the status of these organisms is uncertain (Unz \& Head, 2005). 
During the last two decades, the development of molecular biological tools has led to a significant improvement in the field of classification and identification of micro-organisms. Molecular approaches based not only on analysis of the 16S rRNA gene, but also on several housekeeping genes, including $h s p 60, g y r B, r p o D, r p o B$ and $d n a J$, have gained in importance because they allow better discrimination of taxa, especially at the species and strain levels (Yamamoto \& Harayama, 1998; Kwok et al., 1999; Blackwood et al., 2000). The functional genes $h s p 60$ (encoding the $60 \mathrm{kDa}$ chaperonin) and $g y r B$ (encoding the subunit B protein of DNA gyrase) can be used as additional phylogenetic markers, being characterized by higher rates of evolution in comparison with the $16 \mathrm{~S}$ rRNA gene and by universality, being present in each genome as a single copy. For several bacteria, a good correlation between DNA-DNA hybridization data and analysis of $h s p 60$ and gyrB gene sequences has been shown (Hatano \& Nishii, 1994; Kwok et al., 1999; Yamamoto et al., 1999; Jian et al., 2001).

In a previous study, we found a mass development of filamentous sulfur bacteria as bacterial mats in sulfide springs of the Northern Caucasus region. According to a phylogenetic in situ/ex situ analysis, the bacterial mats were dominated by representatives of the genus Thiothrix (Chernousova et al., 2008). In this work, we present the comparative analysis of five novel strains of the genus Thiothrix obtained from these mats by means of a polyphasic approach including molecular, chemotaxonomic and phenotypic characterization.

Strains $\mathrm{G}^{\mathrm{T}}, \mathrm{G} 2, \mathrm{P}$ and $\mathrm{K} 2$ were isolated from bacterial mats of different sulfide springs located in the northern spurs of the Central Caucasus Ridge, in Krasnodar and Stavropol Krai, Russia. These sulfide springs are formed from outflows of deep sulfidic waters and have a temperature of nearly $40{ }^{\circ} \mathrm{C}$. Bacterial mats containing sulfur inclusions are visible and are abundant on drains of the sulfidic waters and on the surfaces of rocks. Strains $G 1^{\mathrm{T}}$ and G2 were isolated from the Petushok spring, strain P was from bacterial mats of Proval lake and strain K2 was from Kabardinskii spring. The bacterial mats from which strains $\mathrm{G1}^{\mathrm{T}}, \mathrm{G} 2, \mathrm{P}$ and $\mathrm{K} 2$ were isolated developed at 33$40{ }^{\circ} \mathrm{C}, \mathrm{pH} 7.3-7.5$ and at a sulfide concentration in the water of 3.8-6.4 $\mathrm{mg} \mathrm{l}^{-1}$.

Strain $\mathrm{BL}^{\mathrm{T}}$ was isolated from bacterial mats located at a shallow site of a lower lake of the Blue lake system (Kabardino-Balkaria). It is the deepest karstic lake in Russia $(365 \mathrm{~m})$ and is located at $809 \mathrm{~m}$ above sea level. The temperature at the surface of the lake is constant yearround at $9.3{ }^{\circ} \mathrm{C}$ and the sulfide concentration is maintained at $3.1 \mathrm{mg} \mathrm{l}^{-1}$ at $\mathrm{pH}$ 7.5.

Isolation of pure cultures was carried out on Armbruster medium (Armbruster, 1969). Strains G1 ${ }^{\mathrm{T}}, \mathrm{G} 2, \mathrm{P}, \mathrm{K} 2$ and $\mathrm{BL}^{\mathrm{T}}$ were incubated at $25^{\circ} \mathrm{C}$ for $48 \mathrm{~h}$.

Strains $\mathrm{G}^{\mathrm{T}}{ }^{\mathrm{T}}, \mathrm{G} 2, \mathrm{~K} 2, \mathrm{P}$ and $\mathrm{BL}^{\mathrm{T}}$ were analysed by randomly amplified polymorphic DNA-PCR (RAPD-PCR). The cells were disrupted by three cycles of freezing to $-70{ }^{\circ} \mathrm{C}$ and thawing at $50{ }^{\circ} \mathrm{C}$ with subsequent heating of the cell suspension at $85{ }^{\circ} \mathrm{C}$ for $5 \mathrm{~min}$ (Bej et al., 1991). DNA was extracted by the phenol method (Ausubel et al., 1994). Genomic RAPD fingerprints were obtained as described by De Bruijn (1992) using the primer M13 (5'-TTATGTAAAACGACGGCCAGT-3') with subsequent analysis by electrophoresis in $1.5 \%(\mathrm{w} / \mathrm{v})$ agarose gels (Supplementary Fig. S1, available in IJSEM Online). Most of the amplified fragments were between 300 and 2000 bp. Strains $\mathrm{G1}^{\mathrm{T}}$, G2, $\mathrm{P}$ and K2 shared similar PCR patterns between 900 and $2000 \mathrm{bp}$, while strain $\mathrm{BL}^{\mathrm{T}}$ differed markedly from the other strains in the presence of five fragments between 500 and $1700 \mathrm{bp}$. The RAPD fingerprint patterns obtained were converted into a binary data matrix by scoring the presence of a band as 1 and its absence as 0 . Bands that were not reproducible were excluded from the analyses. Faint and visually indistinguishable bands were also ignored. The binary matrix was subjected to the FreeTree 0.9.1.50 software (Hampl et al., 2001), using the Nei and Li coefficient (Nei \& Li, 1979) to generate a similarity matrix. The lowest similarity (approx. 20\%) was reached between strain $\mathrm{BL}^{\mathrm{T}}$ and all the other isolated Thiothrix strains. High genetic similarity, above $75 \%$, was observed between strains $\mathrm{G1}^{\mathrm{T}}, \mathrm{G} 2, \mathrm{P}$ and $\mathrm{K} 2$.

Cell morphology was observed by using an Olympus CX 4 microscope equipped with a phase-contrast device and by transmission electron microscopy with an accelerating voltage of $60 \mathrm{kV}$. The cell morphology of all strains was similar. Rod-shaped cells, arranged in chains, were seriate in trichomes within a polysaccharide sheath (Fig. 1c). Gliding gonidia were produced from the apex. At the base, the trichomes formed a holdfast. When organisms were grown in the presence of a reduced inorganic sulfur compound, sulfur globules were deposited within cells (Fig. 1a). The top cells of short filaments sometimes formed pin-like bulges during the stationary growth phase (Fig. 1d). In the early stages of exponential growth, spiral forms of filaments were often observed for strains $\mathrm{G} 1^{\mathrm{T}}$, G2, $\mathrm{P}$ and $\mathrm{K} 2$ (a micrograph for strain $\mathrm{G1}^{\mathrm{T}}$ is shown in Fig. 1b).

Physiological and biochemical properties of the strains were determined using standard methods (Gerhardt et al., 1981). Morphological and physiological properties of the strains are compared in Tables 1 and 2. All strains were able to grow heterotrophically, autotrophically with thiosulfate or sulfide and also mixotrophically using a combination of reduced sulfur compounds and lactate. Thiosulfate or sulfide were oxidized to sulfate and element sulfur.

Strains $\mathrm{G}^{\mathrm{T}}, \mathrm{G} 2, \mathrm{P}$ and $\mathrm{K} 2$ grew on medium without a nitrogen source and were capable of nitrogen assimilation, but strain $\mathrm{BL}^{\mathrm{T}}$ was not. The ability of the strains to fix nitrogen was confirmed by the acetylene reduction assay (Stewart et al., 1968).

On the basis of RAPD analysis, physiological and morphological data, strains $\mathrm{G} 1^{\mathrm{T}}, \mathrm{G} 2, \mathrm{P}$ and $\mathrm{K} 2$ can be considered as members of the same species. Strains $\mathrm{Gl}^{\mathrm{T}}$ 


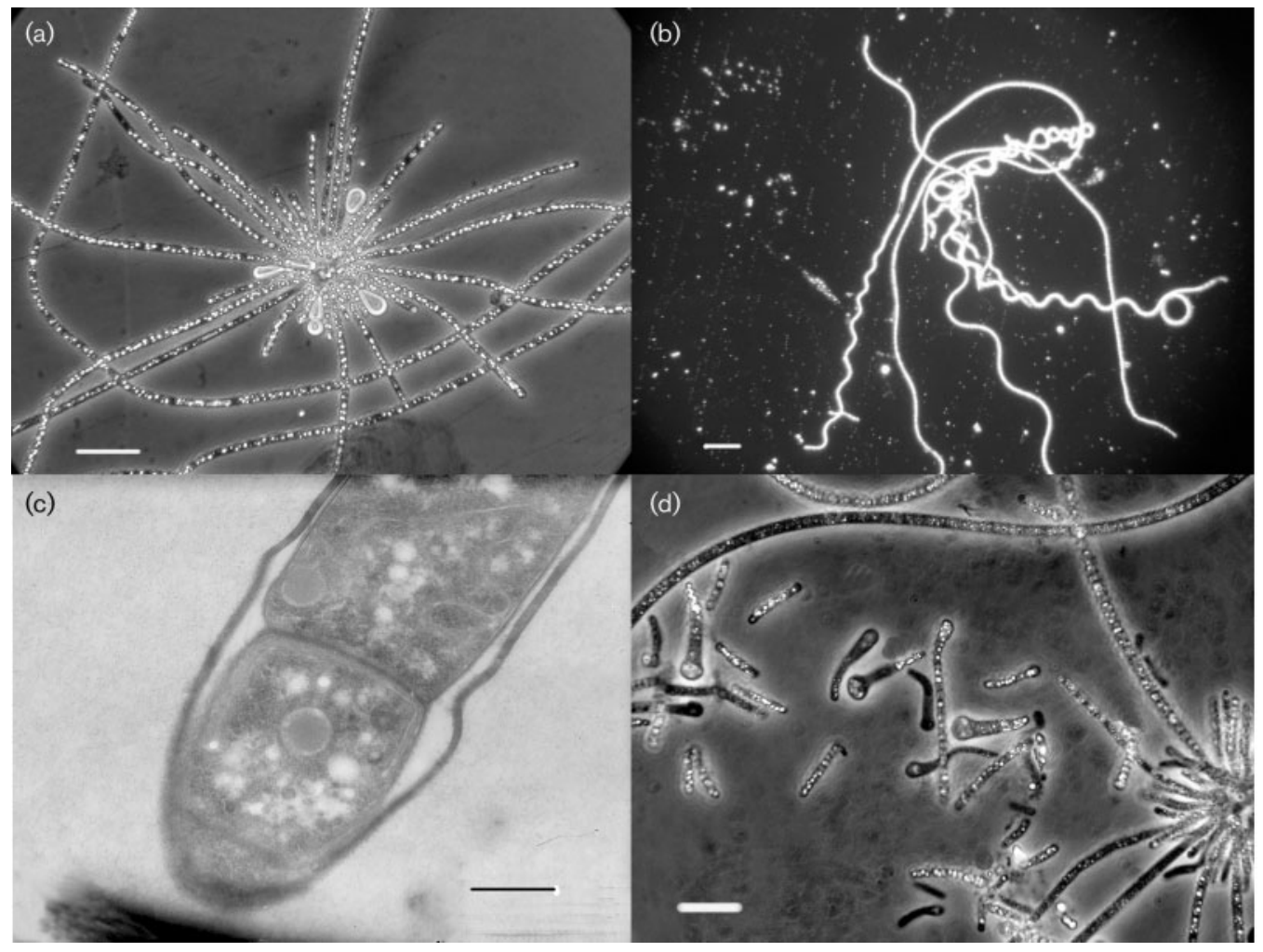

Fig. 1. Morphology of strains $B L^{\top}(a, c)$ and $G 1^{\top}(b, d)$. (a) Rosette with sulfur globules; (b) helical cell shape; (c) mucous cover around cells; (d) modified end cells of trichome. Bars, $10 \mu \mathrm{m}(\mathrm{a}), 20 \mu \mathrm{m}$ (b, d) and $1 \mu \mathrm{m}$ (c).

(as a representative of the first group) and $\mathrm{BL}^{\mathrm{T}}$ were studied in more detail.

The $16 \mathrm{~S}$ rRNA genes of $\mathrm{Gl}^{\mathrm{T}}$ and $\mathrm{BL}^{\mathrm{T}}$ were amplified using primers 27f (5'-AGAGTTTGATCCTGGCTCAG-3') and 1492r (5'-TACGGYTACCTTGTTACGACTT-3') (Lane, 1991; Medlin et al., 1988). The PCR products were sequenced by using a CEQ2000 XL automatic sequencer (Beckman Coulter). The known closest relatives of the new isolates were determined by performing sequence database searches and the sequences of closely related strains were retrieved from the GenBank (NCBI; http://www.ncbi.nlm. nih.gov) or Ribosomal Database Project (RDPII; http:// rdp.cme.msu.edu) libraries. Aligning of $16 \mathrm{~S}$ rRNA gene sequences was carried out using the CLUSTAL_X software package (Thompson et al., 1997). An evolutionary-distance matrix was calculated using the algorithm of Jukes \& Cantor (1969). A phylogenetic tree was constructed using the neighbour-joining method. Bootstrap analysis was based on 1000 resamplings. The TREECON software package was used for phylogenetic analysis (Van de Peer \& De Wachter, 1994).

On the basis of the distance matrix, 16S rRNA gene sequence similarities indicated that the closest phylogenetic relatives of strains $\mathrm{BL}^{\mathrm{T}}$ and $\mathrm{Gl}^{\mathrm{T}}$ are two strains of $T$. fructosivorans, strain I (98.8 and $98.7 \%$ similarity, respectively) and strain $\mathrm{Q}^{\mathrm{T}}$ (98.8 and $\left.98.9 \%\right)$, and the sheathed, filamentous bacterium strain CT3 (99.1 and
$99.0 \%$ similarity). Thiothrix sp. CT3 was isolated from an activated sludge treatment plant in Italy by Rossetti et al. (2003). These authors showed that there are several differences between Thiothrix sp. CT3 and T. fructosivorans, but did not propose a novel species for Thiothrix sp. CT3. Strains $\mathrm{BL}^{\mathrm{T}}$ and $\mathrm{G}^{\mathrm{T}}$ shared $98.8 \%$ sequence similarity (Supplementary Table S1). The 16S rRNA gene sequence similarity between strains $\mathrm{BL}^{\mathrm{T}}$ and $\mathrm{Gl}^{\mathrm{T}}$ and the other two species of the co-called Thiothrix nivea group, T. unzii and T. nivea, was respectively $94.5-94.9$ and $94.0-95.1 \%$. A phylogenetic tree based on 16S rRNA gene sequences is shown in Fig. 2.

The type strain of T. fructosivorans, strain ATCC $49748^{\mathrm{T}}$ $\left(=\right.$ strain $\left.\mathrm{Q}^{\mathrm{T}}\right)$, was replaced in further investigations by ATCC 49749 (=strain I), because the culture of strain ATCC $49748^{\mathrm{T}}$ obtained from the ATCC did not grow. The high level of sequence similarity between strains I and $\mathrm{Q}^{\mathrm{T}}$ (16S rRNA gene, 99.4\%; hsp60, 99.8\%; Supplementary Table S1) and their extremely similar phenotypic properties (Howarth et al., 1999) indicate that the two strains belong to the same species. Additionally, they were isolated from the same activated-sludge plant (Williams \& Unz, 1985). Therefore, the use of strain ATCC 49749 instead of the type strain for comparative analysis of $g y r B$ genes and for DNA-DNA hybridization studies seems justified. Thiothrix sp. CT3 was obtained as strain DSM 12730. 
Table 1. Differential characteristics of strains $\mathrm{BL}^{\top}$ and $\mathrm{G} 1^{\top}$, Thiothrix sp. CT3 and T. fructosivorans I

Strains: $1, \mathrm{BL}^{\mathrm{T}} ; 2, \mathrm{Gl}^{\mathrm{T}}$ (properties of strains $\mathrm{G} 1^{\mathrm{T}}, \mathrm{G} 2, \mathrm{P}$ and $\mathrm{K} 2$ were highly similar; therefore, only data for strain $\mathrm{G} 1^{\mathrm{T}}$ are presented); 3, Thiothrix sp. CT3 (data from Rossetti et al., 2003); 4, T. fructosivorans I (=ATCC 49749) (Howarth et al., 1999). For all strains, starch, gelatin, casein are not hydrolysed; sulfide is not formed from cysteine and thiosulfate, indole is not produced, nitrate and fumarate are not used as electron acceptors, no growth is observed in $3 \% \mathrm{NaCl}$, pigments are not formed when cells are grown on aromatic amino acids and acid is not produced from sugars. All strains are positive for oxidase activity and reduction of nitrate to nitrite. All strains utilize acetate, succinate, lactate and pyruvate and do not utilize benzoate, salicylate, glyoxylate, glycolate; mannitol, sorbitol, glycerol, ethanol, butanol, isobutanol, propanol, inositol; lactose, D-glucose, D-galactose, L-sorbose, D-mannose, trehalose; serine, lysine, tryptophan, histidine, phenylalanine, methionine, tyrosine, proline, ornithine, glutamine, peptone, yeast extract or casein hydrolysate.

\begin{tabular}{|c|c|c|c|c|}
\hline Characteristic & 1 & 2 & 3 & 4 \\
\hline Cell width $(\mu \mathrm{m})$ & $0.9-2.3$ & $0.9-2.2$ & $0.8-2.0$ & $1.0-1.7$ \\
\hline Cell length $(\mu \mathrm{m})$ & $4.4-6.3$ & $3.2-6.5$ & $4.3-6.7$ & $4.9-10.0$ \\
\hline \multicolumn{5}{|l|}{$\mathrm{pH}$ for growth } \\
\hline Range & $6.2-8.2$ & $7.0-8.6$ & $7.0-8.0$ & $6.7-8.0$ \\
\hline Optimum & 7.0 & 8.0 & 7.6 & $7.6-8.0$ \\
\hline \multicolumn{5}{|l|}{ Temperature for growth $\left({ }^{\circ} \mathrm{C}\right)$} \\
\hline Range & $5-32$ & $7-37$ & $10-30$ & $5-32$ \\
\hline Optimum & 24 & 25 & $20-24$ & $25-27$ \\
\hline DNA G $+\mathrm{C}$ content $(\mathrm{mol} \%)\left(T_{\mathrm{m}}\right)$ & 51.4 & 52 & 53.4 & 51.5 \\
\hline \multicolumn{5}{|l|}{ Utilization of carbon sources } \\
\hline Malate & - & - & - & + \\
\hline Fumarate & + & + & - & + \\
\hline Oxalate & + & - & - & + \\
\hline Oxaloacetate & + & + & - & + \\
\hline Citrate & + & - & - & - \\
\hline Isocitrate & + & - & - & + \\
\hline 2-Oxoglutarate & + & - & - & - \\
\hline Formate & - & - & - & + \\
\hline Aconitate & + & - & - & - \\
\hline Malonate & + & - & - & - \\
\hline L-Arabinose & - & - & - & + \\
\hline Raffinose & - & - & - & + \\
\hline Sucrose & - & - & - & + \\
\hline Maltose & - & - & - & + \\
\hline D-Fructose & - & - & - & + \\
\hline D-Xylose & - & - & - & + \\
\hline L-Rhamnose & - & - & - & + \\
\hline Glutamate & + & - & - & - \\
\hline Aspartate & + & + & - & - \\
\hline Cysteine & + & - & - & - \\
\hline Cystine & + & - & - & - \\
\hline Asparagine & + & - & - & - \\
\hline Leucine & - & + & - & - \\
\hline Isoleucine & - & + & - & - \\
\hline Catalase activity & - & - & - & + \\
\hline Assimilation of nitrogen & - & + & - & - \\
\hline
\end{tabular}

The hsp60 gene was amplified from genomic DNA of isolates $\mathrm{BL}^{\mathrm{T}}$ and $\mathrm{Gl}^{\mathrm{T}}$ as well as T. fructosivorans ATCC 49749 (=I) and Thiothrix sp. DSM 12730 (=CT3) using universal hsp60 degenerate primers $\mathrm{H} 1612 \quad\left(5^{\prime}-\right.$ GAIIIIGCIGGYGACGGYACSACSAC-3') and H1613 (5'CGRCGRTCRCCGAAGCCSGGIGCCTT-3') under the PCR conditions given by Hill et al. (2006). The expected $550 \mathrm{bp}$ amplification product was purified and sequenced.
Sequences were compared with sequences in the GenBank database via BLAST (Altschul et al., 1997). The analysis revealed the highest sequence similarity with the hsp60 genes of $T$. fructosivorans $\mathrm{Q}^{\mathrm{T}}(91.2$ and $91.5 \%$, respectively, for strains $\mathrm{BL}^{\mathrm{T}}$ and $\mathrm{Gl}^{\mathrm{T}}$ ) and Thiothrix sp. DSM $12730(89.8$ and $85.5 \%)$. Strains $\mathrm{BL}^{\mathrm{T}}$ and $\mathrm{Gl}^{\mathrm{T}}$ shared $88.4 \%$ sequence similarity (Supplementary Table S1). 
Table 2. Characteristics that differentiate strains $\mathrm{BL}^{\top}$ and $\mathrm{G} 1^{\top}$ from other Thiothrix species

Strains: 1, $\mathrm{BL}^{\mathrm{T}}$ 2, $\mathrm{G1}^{\mathrm{T}} ; 3$, T. fructosivorans $\mathrm{Q}^{\mathrm{T}} ; 4$, T. unzii $\mathrm{Al}^{\mathrm{T}} ; 5$, T. nivea $\mathrm{JP} 2^{\mathrm{T}} ; 6$, T. flexilis $\mathrm{EJ} 2 \mathrm{M}-\mathrm{B}^{\mathrm{T}} ;$ 7, T. disciformis $\mathrm{B} 3-1^{\mathrm{T}} ; 8$, T. eikelboomii $\mathrm{AP}^{\mathrm{T}}$. Data were taken from this study and from Williams \& Unz (1985), Howarth et al. (1999) (T. unzii and T. fructosivorans), Larkin \& Shinabarger (1983) (T. nivea) and Aruga et al. (2002) (type 021N group). +, Positive; -, negative; \pm , weakly positive; ND, no data available.

\begin{tabular}{|c|c|c|c|c|c|c|c|c|}
\hline \multirow[t]{2}{*}{ Characteristic } & \multicolumn{5}{|c|}{ T. nivea group } & \multicolumn{3}{|c|}{ Type $021 \mathrm{~N}$} \\
\hline & 1 & 2 & 3 & 4 & 5 & 6 & 7 & 8 \\
\hline Sheath & + & + & + & - & + & - & - & - \\
\hline Nitrate reduction & + & + & + & + & + & + & - & + \\
\hline DNA G $+C$ content $(\mathrm{mol} \%)$ & 51.4 & 52 & $51.5^{\star}$ & ND & 52 & $44.0-44.4 \dagger$ & $43.9-44.7 \dagger$ & $44.1-46.1 \dagger$ \\
\hline Catalase activity & - & - & \pm & - & - & + & + & + \\
\hline Assimilation of nitrogen & - & + & - & $\mathrm{ND}$ & + & ND & $\mathrm{ND}$ & $\mathrm{ND}$ \\
\hline \multicolumn{9}{|l|}{ Utilization of carbon sources } \\
\hline Malate & - & - & + & + & + & ND & ND & + \\
\hline Fumarate & + & + & + & + & - & ND & ND & + \\
\hline 2-Oxoglutarate & + & - & - & - & $\mathrm{ND}$ & ND & $\mathrm{ND}$ & + \\
\hline Formate & - & - & + & + & - & - & - & - \\
\hline Lactate & + & + & + & + & - & + & - & + \\
\hline Sucrose, D-fructose & - & - & + & - & - & + & + & + \\
\hline Maltose, D-glucose, trehalose, mannitol & - & - & - & - & - & + & + & + \\
\hline Aspartate & + & + & - & - & - & + & + & ND \\
\hline Glutamate & + & - & - & - & - & + & + & + \\
\hline Cysteine, cystine, asparagine & + & - & - & - & $\mathrm{ND}$ & ND & ND & - \\
\hline Leucine, isoleucine & - & + & - & - & $\mathrm{ND}$ & ND & $\mathrm{ND}$ & - \\
\hline
\end{tabular}

${ }^{*}$ Data for T. fructosivorans I.

$\dagger$ Ranges of values for a number of strains including the type strains (Aruga et al., 2002).

The $g y r B$ gene was amplified by PCR using universal $g y r B$ primers Up1 (5'-GAAGTCATCATGACCGTTCTGCAYGCNGGNGGNAARTTYGA-3') and Up2r (5'-AGCAGGGTACGGATGTGCGAGCCRTCNACRTCNGCRTCNGTCAT-3') (Yamamoto \& Harayama, 1998). Strains $\mathrm{BL}^{\mathrm{T}}$ and $\mathrm{Gl}^{\mathrm{T}}$ shared $83.1 \%$ sequence similarity and showed

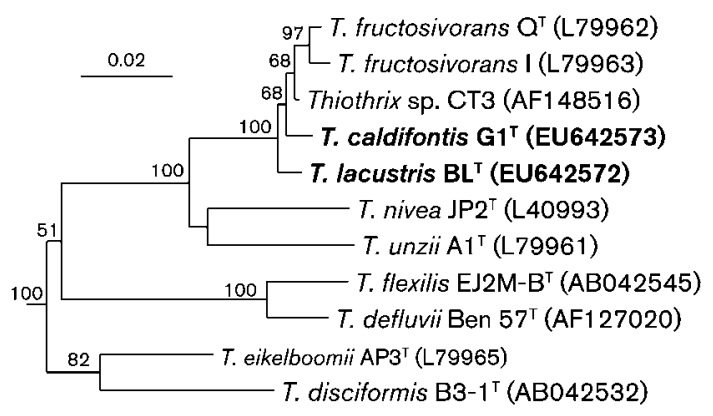

Fig. 2. Neighbour-joining phylogenetic tree based on $16 \mathrm{~S}$ rRNA gene sequences, showing the position of strains $\mathrm{G}_{1}^{\top}$ and $\mathrm{BL}^{\top}$ among their phylogenetic neighbours. Numbers at branch nodes are bootstrap values expressed as percentages of 1000 replicates (only values above $50 \%$ are shown). Bar, 0.02 substitutions per nucleotide position. The tree was rooted using the sequence of Achromatium oxaliferum clone 5 (GenBank accession no. L42543) as an outgroup (not shown).
83.6 and $85.4 \%$ gyrB sequence similarity, respectively, to $T$. fructosivorans ATCC 49749 and $84.5 \%$ to Thiothrix sp. DSM 12730 (Supplementary Table S1).

A fragment of the nifH gene was obtained for strains $\mathrm{Gl}^{\mathrm{T}}$, $\mathrm{G} 2, \mathrm{P}$ and $\mathrm{K} 2$ but not for strain $\mathrm{BL}^{\mathrm{T}}$ by PCR using primers F1 (5' -TAYGGIAARGGIAARGGIGGIATIGGIAARTC-3') and nifH-3r (5'-TTGTTGGCIGCRTASAKIGCCATT-3'), as described by Fedorov et al. (2008).

Fatty acid analysis was done by using the Microbial Identification System (Sherlock; MIDI Inc.) according to standard protocols (Stead et al., 1992). Fatty acid profiles of strains $\mathrm{Gl}^{\mathrm{T}}$ and $\mathrm{BL}^{\mathrm{T}}$ are given in Table 3. The dominant components were $\mathrm{C}_{16: 1} \omega 7, \mathrm{C}_{16: 0}$ and $\mathrm{C}_{18: 1} \omega 7$. The 3hydroxy fatty acids $\mathrm{C}_{10: 0} 3-\mathrm{OH}$ and iso- $\mathrm{C}_{15: 0} 3-\mathrm{OH}$ were found in strain $\mathrm{Gl}^{\mathrm{T}}$ only.

DNA base composition was determined by the thermal denaturation method as described previously (Owen \& Lapage, 1976). The molar DNA G $+\mathrm{C}$ contents of strains $\mathrm{BL}^{\mathrm{T}}$ and $\mathrm{Gl}^{\mathrm{T}}$ were 51.4 and $52 \%$, respectively, in accordance with values usually reported for members of the genus Thiothrix (43-53 mol\%) (Aruga et al., 2002).

DNA-DNA relatedness was determined by measuring the renaturation rates of the denatured DNAs at the optimal renaturation temperatures as recommend by De Ley et al. (1970). A Pye Unicam SP 1800 spectrophotometer equipped with a thermoprogrammer and hermetically 
Table 3. Comparison of the cellular fatty acid contents of strains $\mathrm{BL}^{\top}, \mathrm{G}_{1}{ }^{\top}$, Thiothrix sp. CT3 and T. fructosivorans I

Strains: $1, \mathrm{G1}^{\mathrm{T}} ; 2, \mathrm{BL}^{\mathrm{T}} ; 3$, CT3 (data obtained in this study for strain DSM 12730); 4, T. fructosivorans I (data obtained in this study for strain ATCC 49749). Values are percentages of the total peak area. -, Not detected.

\begin{tabular}{|c|c|c|c|c|}
\hline Fatty acid & 1 & 2 & 3 & 4 \\
\hline $\mathrm{C}_{12: 0}$ & - & - & - & 1.1 \\
\hline $\mathrm{C}_{10: 0} 3-\mathrm{OH}$ & 0.4 & - & - & - \\
\hline iso- $\mathrm{C}_{14: 0}$ & 0.8 & - & - & - \\
\hline $\mathrm{C}_{14: 0}$ & 0.9 & - & 0.8 & 2.2 \\
\hline iso- $\mathrm{C}_{15: 0}$ & 1.0 & - & - & 1.6 \\
\hline anteiso- $\mathrm{C}_{15: 0}$ & 1.2 & - & - & 1.6 \\
\hline $\mathrm{C}_{15: 0}$ & - & - & - & 1.2 \\
\hline iso- $\mathrm{C}_{16: 0}$ & 1.0 & - & - & - \\
\hline $\mathrm{C}_{16: 1} \omega 7$ & 38.7 & 64.5 & 45.7 & 39.3 \\
\hline$C_{16: 0}$ & 26.7 & 10.9 & 18.0 & 22.5 \\
\hline iso- $\mathrm{C}_{15: 0} 3-\mathrm{OH}$ & 1.3 & - & - & - \\
\hline $\mathrm{C}_{18: 1} \omega 7$ & 27.3 & 24.6 & 34.2 & 28.1 \\
\hline $\mathrm{C}_{18: 0}$ & 0.7 & - & 1.3 & 2.4 \\
\hline
\end{tabular}

sealed thermocuvettes was used. Strains $\mathrm{BL}^{\mathrm{T}}$ and $\mathrm{G1}^{\mathrm{T}}$ shared $35 \%$ DNA-DNA relatedness, and respectively showed 51 and $53 \%$ relatedness to $T$. fructosivorans ATCC 49749 (Supplementary Table S2).

The phenotypic and genotypic characteristics described above suggest that strain $\mathrm{Gl}^{\mathrm{T}}$ and $\mathrm{BL}^{\mathrm{T}}$ differ at the species level from previously described species of the genus Thiothrix and from each other. Therefore, we propose the names Thiothrix caldifontis sp. nov. for strains $\mathrm{Gl}^{\mathrm{T}}, \mathrm{G} 2, \mathrm{~K} 2$ and $\mathrm{P}$ and Thiothrix lacustris sp. nov. for strain $\mathrm{BL}^{\mathrm{T}}$.

\section{Description of Thiothrix caldifontis sp. nov.}

Thiothrix caldifontis (cal.di.fon'tis. L. adj. caldus hot; L. n. fons, fontis a spring; N.L. gen. n. caldifontis from a hot spring, pertaining to the source of isolation of the first strains).

Rod-shaped cells with rounded ends, seriate in multicellular filaments (trichomes) with polysaccharide sheaths. Gram-negative and aerobic. Cells of the major form are $0.9-2.2 \mu \mathrm{m}$ in diameter and 3.2-6.5 $\mu \mathrm{m}$ long. Filaments are non-motile. Gliding gonidia are produced from the apical ends of the filaments. Gonidia can form rosettes. At early stages of exponential growth, a spiral form of filaments is often observed. The top cells of short filaments sometimes form pin-like bulges during the stationary growth phase. Colonies are white with fibrous edges, $1-5 \mathrm{~mm}$ in diameter. The temperature range for growth is $7-37{ }^{\circ} \mathrm{C}$, with optimum growth at $25{ }^{\circ} \mathrm{C}$. The $\mathrm{pH}$ range for growth is 7.0-8.6, with optimum growth at $\mathrm{pH}$ 8.0. A number of organic acids, including acetate, lactate, pyruvate, oxaloacetate, fumarate and succinate, and amino acids, including aspartate, leucine and isoleucine, are utilized as carbon and energy sources for chemo-organoheterotrophic growth.
Alcohols, sugars, peptone and casein hydrolysate are not used. Peptone, yeast extract, ammonium, nitrate and nitrite are used as sole nitrogen sources. Anaerobic growth with nitrate does not occur. Capable of nitrogen fixation. Negative in tests for catalase activity and hydrolysis of starch and casein. Positive in tests for oxidase and urease activities. During growth with cysteine or thiosulfate, no sulfide is formed. Capable of lithotrophic growth in the presence of reduced sulfur compounds. Thiosulfate and sulfide are oxidized to sulfate and element sulfur. Maximum cell counts are obtained during mixotrophic growth in the presence of thiosulfate, lactate and other organic substrates. The major fatty acids are $\mathrm{C}_{16: 1} \omega 07$, $\mathrm{C}_{16: 0}, \mathrm{C}_{18: 1} \omega 7$; among the minor components, the 3hydroxy fatty acids $\mathrm{C}_{10: 0} 3-\mathrm{OH}$ and iso- $\mathrm{C}_{15: 0} 3-\mathrm{OH}$ are found. The $\mathrm{G}+\mathrm{C}$ content of the DNA of the type strain is $52 \mathrm{~mol} \%\left(T_{\mathrm{m}}\right)$.

The type strain is strain $\mathrm{Gl}^{\mathrm{T}}\left(=\mathrm{DSM} 21228^{\mathrm{T}}=\mathrm{VKM}\right.$ B$2520^{\mathrm{T}}$ ), isolated from the sulfide spring Petushok, at $33-40{ }^{\circ} \mathrm{C}$, in the Northern Caucasus region, Russia. Additional strains are G2, P and K2.

\section{Description of Thiothrix lacustris sp. nov.}

Thiothrix lacustris (la.cus'tris. N.L. fem. adj. lacustris belonging to a lake, referring to the site from where the type strain was isolated).

Rod-like cells with rounded ends occur in sheathed filaments. Gram-negative and aerobic. Cells of the major form are $0.9-2.3 \mu \mathrm{m}$ in diameter and $4.4-6.3 \mu \mathrm{m}$ long. Filaments are non-motile. Gliding gonidia are produced from the apical ends of the filaments. Gonidia can produce rosettes. At early stages of exponential growth, a spiral form of filaments is often observed. During the stationary growth phase, pin-like bulges can appear on the ends of short filaments. Colonies are white with fibrous edges, 1$5 \mathrm{~mm}$ in diameter. The temperature range for growth is 5$32{ }^{\circ} \mathrm{C}$, with optimum growth at $24{ }^{\circ} \mathrm{C}$. The $\mathrm{pH}$ range for growth is 6.2-8.2, with optimum growth at $\mathrm{pH}$ 7.0. A number of organic acids, including acetate, lactate, pyruvate, succinate, fumarate, oxalate, oxaloacetate, 2oxoglutarate, citrate, isocitrate, malonate and aconitate, and amino acids, including aspartate, glutamate, cysteine, cystine and asparagine, are utilized as carbon and energy sources for chemo-organoheterotrophic growth. Alcohols, sugars, peptone and casein hydrolysate are not used. Peptone, yeast extract, ammonium, nitrate and nitrite are used as sole nitrogen sources. Anaerobic growth with nitrate does not occur. Incapable of nitrogen fixation. Negative in tests for catalase activity and hydrolysis of starch and casein. Positive in tests for oxidase and urease activities. During growth with cysteine or thiosulfate, sulfide is not formed. Capable of lithotrophic growth in the presence of reduced sulfur compounds. Thiosulfate and sulfide are oxidized to sulfate and element sulfur. Maximum cell counts are obtained during mixotrophic growth in the presence of thiosulfate, lactate (or other 
organic substrates). The major fatty acids are $\mathrm{C}_{16: 1} \omega 7$, $\mathrm{C}_{16: 0}$ and $\mathrm{C}_{18: 1} \omega 7$. The $\mathrm{G}+\mathrm{C}$ content of the DNA of the type strain is $51.4 \mathrm{~mol} \%\left(T_{\mathrm{m}}\right)$.

The type strain is strain $\mathrm{BL}^{\mathrm{T}}\left(=\mathrm{DSM} 21227^{\mathrm{T}}=\mathrm{VKM} \mathrm{B}-\right.$ $2521^{\mathrm{T}}$ ), isolated from a low-temperature lake of the Blue lake system (Kabardino-Balkaria).

\section{Acknowledgements}

The authors wish to thank Dr E. Detkova for analysis of the molar $\mathrm{G}+\mathrm{C}$ contents of the DNA and DNA-DNA hybridization, Dr G. A. Osipov for performing cellular fatty acid analysis of strains, Dr D. Yu. Sorokin and Dr I. K. Kravchenko for analysis of the ability to fix $\mathrm{N}_{2}$ by means of the acetylene reduction assay and Victoria Bukreeva for technical assistance. This work was supported by grants from the Russian Foundation for Fundamental Research (05-04-48299, 07-0400651) and the Program of Presidium of Russian Academy of Sciences 'Molecular and Cell Biology'.

\section{References}

Altschul, S. F., Madden, T. L., Schäffer, A. A., Zhang, J., Zhang, Z., Miller, W. \& Lipman, D. J. (1997). Gapped BLAST and PSI-BLAST: a new generation of protein database search programs. Nucleic Acids Res 25, 3389-3402.

Armbruster, E. H. (1969). Improved technique for isolation and identification of Sphaerotilus. Appl Microbiol 17, 320-321.

Aruga, S., Kamagata, Y., Kohno, T., Hanada, S., Nakamura, K. \& Kanagawa, T. (2002). Characterization of filamentous Eikelboom type $021 \mathrm{~N}$ bacteria and description of Thiothrix disciformis sp. nov. and Thiothrix flexilis sp. nov. Int J Syst Evol Microbiol 52, 1309-1316.

Ausubel, F. M., Brent, R., Kingston, R. E., Moore, D. D., Seidman, J. G., Smith, J. A. \& Struhl, K. (editors) (1994). Current Protocols in Molecular Biology. New York: Wiley.

Bej, A. K., Mahbubani, M. H., Dicesare, J. L. \& Atlas, R. M. (1991). Polymerase chain reaction-gene probe detection of microorganisms by using filter-concentrated samples. Appl Environ Microbiol 57, 3529-3534.

Blackwood, K. S., He, C., Gunton, J., Turenne, C. Y., Wolfe, J. \& Kabani, A. M. (2000). Evaluation of recA sequences for identification of Mycobacterium species. J Clin Microbiol 38, 2846-2852.

Chernousova, E. Yu., Akimov, V. N., Gridneva, E. V., Dubinina, G. A. \& Grabovich, M. Yu. (2008). Phylogenetic in situ/ex situ analysis of a sulfur mat microbial community from a thermal sulfide spring in the North Caucasus. Mikrobiologiia 77, 255-260 (in Russian).

De Bruijn, F. J. (1992). Use of repetitive (repetitive extragenic palindromic and enterobacterial repetitive intergenic consensus) sequences and the polymerase chain reaction to fingerprint the genomes of Rhizobium meliloti isolates and other soil bacteria. Appl Environ Microbiol 58, 2180-2187.

De Ley, J., Cattoir, H. \& Reynaerts, A. (1970). The quantitative measurement of DNA hybridization from renaturation rates. Eur $J$ Biochem 12, 133-142.

Fedorov, D. N., Ivanova, E. G., Doronina, N. V. \& Trotsenko, Yu. A. (2008). A new system of degenerate-oligonucleotide primers for detection and amplification of nifHD genes. Mikrobiologiia 77, 286288 (in Russian).

Gerhardt, P., Murray, R. G. E., Costilow, R. N., Nester, E. W., Wood, W. A., Krieg, N. R. \& Phillips, G. B. (editors) (1981). Manual of Methods for General Bacteriology. Washington, DC: American Society for Microbiology.
Hampl, V., Pavlícek, A. \& Flegr, J. (2001). Construction and bootstrap analysis of DNA fingerprinting-based phylogenetic trees with the freeware program FreeTree: application to trichomonad parasites. Int J Syst Evol Microbiol 51, 731-735.

Hatano, K. \& Nishii, T. (1994). Taxonomic studies on Streptomyces violaceoruber group and related species based on gyrB sequences. IFO Res Commun 20, 83-91.

Hill, J. E., Town, J. R. \& Hemmingsen, S. M. (2006). Improved template representation in cpn60 PCR product libraries generated from complex templates by application of a specific mixture of PCR primers. Environ Microbiol 8, 741-746.

Howarth, R., Unz, R. F., Seviour, E. M., Seviour, R. J., Blackall, L. L., Pickup, R. W., Jones, J. G., Yaguchi, J. \& Head, I. M. (1999). Phylogenetic relationships of filamentous sulfur bacteria (Thiothrix spp. and Eikelboom type $021 \mathrm{~N}$ bacteria) isolated from wastewatertreatment plants and description of Thiothrix eikelboomii sp. nov., Thiothrix unzii sp. nov., Thiothrix fructosivorans sp. nov. and Thiothrix defluvii sp. nov. Int J Syst Bacteriol 49, 1817-1827.

Jian, W., Zhu, L. \& Dong, X. (2001). New approach to phylogenetic analysis of the genus Bifidobacterium based on partial HSP60 gene sequences. Int J Syst Evol Microbiol 51, 1633-1638.

Jukes, T. H. \& Cantor, C. R. (1969). Evolution of protein molecules. In Mammalian Protein Metabolism, vol. 3, pp. 21-132. Edited by H. N. Munro. New York: Academic Press.

Kwok, A. Y., Su, S. C., Reynolds, R. P., Bay, S. J., Av-Gay, Y., Dovichi, N. J. \& Chow, A. W. (1999). Species identification and phylogenetic relationships based on partial HSP60 gene sequences within the genus Staphylococcus. Int J Syst Bacteriol 49, 1181-1192.

Lane, D. G. (1991). In Nucleic Acid Techniques in Bacterial Systematics, pp. 115-175. Edited by E. Stackebrandt \& M. Goodfellow. Chichester: Wiley.

Larkin, J. M. \& Shinabarger, D. L. (1983). Characterization of Thiothrix nivea. Int J Syst Bacteriol 33, 841-846.

Medlin, L., Elwood, H. J., Stickel, S. \& Sogin, M. L. (1988). The characterization of enzymatically amplified eukaryotic 16S-like rRNA-coding regions. Gene 71, 491-499.

Nei, M. \& Li, W. H. (1979). Mathematical model for studying genetic variation in terms of restriction endonucleases. Proc Natl Acad Sci U S A 76, 5269-5273.

Owen, R. J. \& Lapage, S. P. (1976). The thermal denaturation of partly purified bacterial deoxyribonucleic acid and its taxonomic applications. J Appl Bacteriol 41, 335-340.

Rossetti, S., Blackall, L. L., Levantesi, C., Uccelletti, D. \& Tandoi, V. (2003). Phylogenetic and physiological characterization of a heterotrophic, chemolithoautotrophic Thiothrix strain isolated from activated sludge. Int J Syst Evol Microbiol 53, 1271-1276.

Stead, D. E., Sellwood, J. E., Wilson, J. \& Winey, I. (1992). Evaluation of a commercial microbial identification system based on fatty acid profiles for rapid, accurate identification of plant pathogenic bacteria. J Appl Bacteriol 72, 315-321.

Stewart, W. D. P., Fitzerald, G. P. \& Burris, R. H. (1968). Acetylene reduction by nitrogen fixing blue-green algae. Arch Mikrobiol 62, 336348.

Thompson, J. D., Gibson, T. J., Plewniak, F., Jeanmougin, F. \& Higgins, D. G. (1997). The CLUSTAL_X windows interface: flexible strategies for multiple sequence alignment aided by quality analysis tools. Nucleic Acids Res 25, 4876-4882.

Unz, R. F. \& Head, I. M. (2005). Genus I. Thiothrix Winogradsky 1888, $39^{\mathrm{AL}}$. In Bergey's Manual of Systematic Bacteriology, 2nd edn, vol. 2, part B, pp. 131-142. Edited by D. J. Brenner, N. R. Krieg, J. T. Staley \& G. M. Garrity. New York: Springer. 
Van de Peer, Y. \& De Wachter, R. (1994). TREECON for Windows: a software package for the construction and drawing of evolutionary trees for the Microsoft Windows environment. Comput Appl Biosci 10, 569-570.

Williams, T. M. \& Unz, R. F. (1985). Filamentous sulfur bacteria of activated sludge: characterization of Thiothrix, Beggiatoa, and Eikelboom type 021N strains. Appl Environ Microbiol 49, 887-898.
Yamamoto, S. \& Harayama, S. (1998). Phylogenetic relationships of Pseudomonas putida strains deduced from the nucleotide sequences of gyrB, rpoD and 16S rRNA genes. Int J Syst Bacteriol 48, 813-819.

Yamamoto, S., Bouvet, P. J. M. \& Harayama, S. (1999). Phylogenetic structure of the genus Acinetobacter based on gyrB sequences: comparison with the grouping by DNA-DNA hybridization. Int $J$ Syst Bacteriol 49, 87-95. 